Editorial

\title{
Vegetation Response to Climate Change and Air Pollution - Unifying Research and Evidence from Northern and Southern Hemisphere
}

From September 1 through 6, 2013, the conference "Vegetation Response to Climate Change and Air Pollution - Unifying Research and Evidence from Northern and Southern Hemisphere" was held in Ilheus, State of Bahia/Brazil, as the 26th biennial convention of the IUFRO Research Group 7.01.00 "Impacts of Air Pollution and Climate Change on Forest Ecosystems" (coordinators Andrzej Bytnerowicz, USA and Elena Paoletti, Italy). This Special Topic contains a number of publications selected from the conference, which was organized by Alessandra R. Kozovits and colleagues (Brazil) as the local hosts, together with Rainer Matyssek (Germany) and Gerhard Wieser (Austria) in developing the scientific concept for the conference.

Main goal of the conference, attended by more than 100 scientists from 26 countries, was to stimulate scientific transhemispheric research collaboration with emphasis on ecosystems of the Southern hemisphere. For the first time the scientific 7.01.00 community met in South America, with particular consideration of research demands in Brazil. Scientific networking was explored on quantitative risk identification regarding health, biodiversity and sustainability of natural and cultivated forests in South America and other parts of the world, fostering mitigation concepts of anthropogenic stress. The focus on forests and other woodyplant ecosystems in Brazil (e.g. on Amazonian and Atlantic rain forests and Cerrado vegetation) was crucial, given their critical role in global carbon storage and buffering of atmospheric $\mathrm{CO}_{2}$ enrichment with associated risks of climate warming and drought exacerbation (Pan et al., 2011).

Such forest and woodland functions are threatened by landuse changes, typically driven by forest burning (Monks et al., 2009), which in turn releases manifold agents and precursors of air pollution (Kozovits and Bustamante, 2013). In Brazil, about $75 \%$ of such agents originate from land-use change rather than emissions from transportation and industrial sectors (MTC, 2009), being responsible, among others, for ozone formation at elevated concentrations in the troposphere as an intrinsic component of climate change (Matyssek et al., 2013a, 2014a). Ozone at enhanced regimes was agreed to be the potentially most toxic air pollutant worldwide to vegetation (cf. Fowler et al., 2008; Mills and Harmens, 2011), in particular to the residual forests, by restricting their carbon storage capacity (Sitch et al., 2007). Such limitation was noted to bear substantial implications for the post-Kyoto discussion. The situation was found to be exacerbated on both hemispheres by enhanced nitrogen deposition from agricultural practices (in addition to combustion of fossil fuels; Bytnerowicz et al., 2013; Kozovits and Bustamante, 2013) and regionally by heavy-metal pollution from open-pit mining (such as in the State of Minas Gerais, Brazil; Veado et al., 2006). A research gap was identified in understanding air pollution effects, as part of climate change, on natural and managed forest and woodland ecosystems. This issue is of high scientific priority because of the ample biological diversity of these ecosystems still present in South America and other parts of the Southern hemisphere. Which is the ecological significance of diversity for ecosystem responsiveness to climate change and air pollution? Another open question were extents to which process-based understanding of climate change and air pollution effects is transferable between hemispheres, given differences in phenologies and lengths of growing seasons. The aim of the conference of "Unifying Research and Evidence from Northern and Southern Hemisphere" was realized, therefore, to be reachable incipiently only at the current stage.

The need for overcoming above knowledge deficits was one of the major conclusions from the conference. To this end, scientific networking capacities are to be established for integrating challenges posed by climate change and air pollution into transhemispheric research collaboration. The stimulating survey of topics and study sites currently operated world-wide that were addressed across eight conference sessions promisingly initiated the needed trans-hemispheric scope. Agreement was attained that reliable understanding of forest ecosystem functioning under climate change and air pollution must be achieved through integration of empirical research, monitoring and process-based, large-scale modeling. This view is in line with the rationale of a recent book publication (Matyssek et al., 2013b), which further develops the concept of a corresponding network of "Supersites in Forest Research" (Mikkelsen et al., 2013; Paoletti et al., 2013) in continuation of initiating accounts by Fischer et al. (2011) and Matyssek et al. (2012). The conference adjourned by proposing a time horizon of about one decade for establishing and interlinking supersites (by integrating existing forest research sites and such to be newly established) into a transcontinental collaboration network and global research concept across the ecologically relevant biomes.

The selection of the following, briefly introducing publications arising from the conference cannot meet, at the current stage, the long-term visions developed about transcontinental research. Nevertheless, the selection shows promising starting points, regarding topics and quality of research, towards the envisioned perspective. The array commences with two contributions from Brazil, e.g. with Rezende et al. (2014) reporting on biochemical assessments of guava saplings (Psidium guajava), exposed to ambient and nearly twice-ambient $\mathrm{CO}_{2}$ concentration in an open-top chamber experiment. Covered were soluble sugars, starch, $\mathrm{C} / \mathrm{N}$ and phenolic compounds. While stimulus on dry mass 
development stayed absent under elevated $\mathrm{CO}_{2}$, starch accumulated conspicuously in the leaves, and so did tannins amongst phenolics at the biochemical level. The latter response is concluded to be a favorable $\mathrm{CO}_{2}$ effect in view of the plants' anti-herbivore capacity. The other study from Brazil demonstrates means of surveilling sulfuric, nitric and heavy-metal emissions from a technologically novel thermoelectric power plant during the stage of assuming operation (Nakazato et al., 2014). Assessed was foliar element accumulation in Lolium multiflorum as a risk indicator, supporting conclusions about the Atlantic Rainforest. The analysis proved $\mathrm{Al}, \mathrm{Co}, \mathrm{Cr}, \mathrm{Cu}, \mathrm{K}, \mathrm{N}, \mathrm{Ni}, \mathrm{S}$, and $\mathrm{Zn}$ (but not so $\mathrm{V}$ ) as appropriate markers in leaf tissue of air contamination, proving failure of the new power plant technology, however, in providing environmental relief.

A different dimension of air pollution is addressed by Fenn et al. (2014), exemplifying Jack pine stands (Pinus banksiana) under nitrogen, sulfur and base cation deposition as released from the oil sand exploitation in the Athabasca region of northern Alberta, Canada. Acidic deposition is concluded to be neutralized by such of base cations, so that eutrophication from $\mathrm{N}$ deposition appears to currently pose a greater risk than does acidification. Regional forest fires are shown to distinctly enhance atmospheric $\mathrm{HNO}_{3}$ and $\mathrm{NH}_{3}$ levels, in the absence, however, of response in $\mathrm{SO}_{2}$. Nitrogen relations are the subject also of Weigt et al. (2014), however, being assessed under chronic $\mathrm{O}_{3}$ stress as employed to adult European beech and Norway spruce trees (Fagus sylvatica and Picea abies, respectively) through free-air canopy fumigation technology at Kranzberg Forest, Germany. Whole-tree N uptake tended to be lowered in both species under twice-ambient $\mathrm{O}_{3}$ levels, while $\mathrm{N}$ allocation was enhanced to fine roots (including mycorrhizal root tips) in beech as opposed to decrease in spruce. High demand for stored $\mathrm{N}$ is concluded in beech to have relevance for tree-internal $\mathrm{N}$ cycling under $\mathrm{O}_{3}$ stress.

For adult beech trees of the same experiment, Matyssek et al. (2014b) demonstrate spatio-temporally consistent $\mathrm{O}_{3}$ uptake (i.e. incorporated $\mathrm{O}_{3}$ doses) by covering cross-canopy and wholeseasonal scopes through sap flow measurement. Although stomatal and canopy conductances were lowered by twice-ambient $\mathrm{O}_{3}$ levels, $\mathrm{O}_{3}$ influx was raised. Nevertheless, stomatal closure, being traceable from leaves across branches to the canopy, proportionally reduced $\mathrm{O}_{3}$ uptake by about $20 \%$ relative to the exposure under the enhanced $\mathrm{O}_{3}$ regime. Quantified is $\mathrm{O}_{3}$ uptake of rainy/overcast days and at night. The approach offers validation of modeled $\mathrm{O}_{3}$ flux in risk assessments for forest trees. The capacity of $\mathrm{O}_{3}$ for narrowing stomatal width became apparent also in trees of Japanese beech (Fagus crenata), being exposed to free-air canopy fumigation technology in Sapporo, Japan, and compared with European beech from Kranzberg Forest by Hoshika et al. (2014). In both species, stomatal response was not accompanied by reduced carboxylation capacity of Rubisco, although photosynthetic net $\mathrm{CO}_{2}$ uptake rate was temporarily restricted to minor extent. Stomatal closure was diminished, however, in fall so that linear decline of opening with $\mathrm{O}_{3}$ influx, if presumed by risk modeling for forest trees, is concluded to be unrealistic.

The array of selected contributions is completed by a phytotron experiment by Ritter et al. (2014), which clarified the allocation of recent photosynthate of juvenile European beech and Norway spruce under twice-ambient $\mathrm{O}_{3}$ exposure and intra vs. interspecific competition. Tracer kinetics in $\mathrm{CO}_{2}$ released from stems were analyzed upon ${ }^{13} \mathrm{CO}_{2} /{ }^{12} \mathrm{CO}_{2}$ labeling. Allocation to stems was significantly lowered by $\mathrm{O}_{3}$ in beech, but was increased in spruce under mixed culture, before effects became apparent each on whole-tree biomass development. Compartmental modeling indicated respiration in spruce to be supplied by recent photosynthate, whereas beech made use of stored carbon. Findings appeared to be related to stem anatomy as contrasting between angiosperm trees and conifers (i.e. beech and spruce, respectively).

\section{References}

Bytnerowicz, A., Fenn, M., McNulty, S., Yuan, F., Pourmokhtarian, A., Driscoll, C. Meixner, T., 2013. Interactive effects of air pollution and climate change on forest ecosystems in the United States - current understanding and future scenarios. In: Matyssek, R., Clarke N,Cudlin, P., Mikkelsen, T., Tuovinen, J.P., Weiser, G., Paoletti, E. (Eds.), Climate Change, Air Pollution and Global Challenges: Understanding and Solutions from Forest Research, Dev. Environ. Sci., vol. 13. Elsevier, Netherlands, pp. 333-369.

Fischer, R., Aas, W., de Vries, W., Clarke, N., Cudlin, P., Leaver, D., Lundin, L., Matteucci G.Matyssek, R., Mikkelsen, T., Mirtl, M., Oeztuerk, Y., Papale, D. Potocic, N., Simpson D,Tuovinen, J.-P., Vesala, T., Wieser, G., Paoletti, E., 2011. Towards a transnational system of supersites for forest monitoring and research in Europe-an overview on present state and future recommendations. iForest-Biogeosci. For. 4, 167-171.

Fenn, M., Bytnerowicz, A., Schilling, S.L., Ross, C.S., 2014. Atmospheric deposition of nitrogen, sulfur and base cations in Jack Pine stands in the athabasca oil sands region, Alberta, Canada. Environ. Pollut. 196, 497-510.

Fowler, D., Amann, M., Anderson, R., Ashmore, M., Cox, P., Depledge, M., Derwent, D., Grennfelt, P., Hewitt, N., Hov O,Jenkin, M., Kelly, F., Liss, P., Pilling, M., Pyle, J., Slingo, J., Stefenson, D., 2008. Ground-level Ozone in the 21st Century: Future Trends, Impacts and Policy Implications. The Royal Society, p. 132. Policy Document.

Hoshika, Y., Watanabe, M., Kitao, M., Haeberle, K.-H., Grams, T.E.E., Koike, T., Matyssek, R., 2014. Ozone induces stomatal narrowing in European and Siebold's beeches: a comparison between two experiments of free-air ozone exposure. Environ. Pollut. 196, 527-533.

Kozovits, A.R., Bustamante, M.M.C., 2013. Land use change, air pollution and climate change-vegetation response in Latin America. In: Matyssek, R., Clarke, N., Cudlin, P., Mikkelsen, T.N., Tuovinen, J.-P., Wieser, G., Paoletti, E. (Eds.), Climate Change, Air Pollution and Global Challenges: Understanding and Perspectives from Forest Research, Developments in Environmental Science, vol. 13. Elsevier, pp. $411-428$.

Matyssek, R., Wieser, G., Calfapietra, C., de Vries, W., Dizengremel, P., Ernst, D., Jolivet, Y., Mikkelsen, T.N., Mohren, G.M.J., le Thiec, D., Tuovinen, J.-P., Weatherall, A., Paoletti, E., 2012. Forests under climate change and air pollution: gaps in understanding and future directions for research. Environ. Pollut. 160, 57-65.

Matyssek, R., Wieser, G., Fleischmann, F., Grünhage, L., 2013a. Ozone Research, quo vadis? lessons from the free-air canopy fumigation experiment at Kranzberg Forest. In: Matyssek, R., Clarke, N., Cudlin, P., Mikkelsen, T.N., Tuovinen, J.-P., Wieser, G., Paoletti, E. (Eds.), Climate Change, Air Pollution and Global Challenges: Understanding and Perspectives from Forest Research, Developments in Environmental Science, vol. 13. Elsevier, pp. 103-129.

Matyssek, R., Clarke, N., Cudlin, P., Mikkelsen, T.N., Tuovinen, J.-P., Wieser, G. Paoletti, E. (Eds.), 2013b. Climate Change, Air Pollution and Global Challenges: Understanding and Perspectives from Forest Research. Developments in Environmental Science, vol. 13. Elsevier, p. 622.

Matyssek, R., Kozovits, A.R., Schnitzler, J., Pretzsch, J., Dieler, J., Wieser, G., 2014a. Forest trees under air pollution as a factor of climate change. In: Tausz, M., Grulke, N. (Eds.), Trees in a Changing Environment, Plant Ecophysiology, vol. 9. Springer, pp. 117-163.

Matyssek, R., Baumgarten, M., Hummel, U., Häberle, K.-H., Kitao, M., Wieser, G., 2014b. Canopy-level stomatal narrowing in adult Fagus sylvatica under $\mathrm{O}_{3}$ stress - means of preventing enhanced $\mathrm{O}_{3}$ uptake under high $\mathrm{O}_{3}$ exposure? Environ. Pollut. 196, 518-526.

Mikkelsen, T.N., Clarke, N., Danielewska, A., Fischer, R., 2013. Towards supersites in forest ecosystem monitoring and research. In: Matyssek, R., Clarke, N., Cudlin, P., Mikkelsen T,Tuovinen, J.-P., Weiser, G., Paoletti, E. (Eds.), Climate Change, Air Pollution and Global Challenges: Understanding and Solutions from Forest Research, Dev. Environ. Sci., vol. 13. Elsevier, Netherlands, pp. $475-496$.

Mills, G. Harmens, H., 2011. Ozone Pollution: a Hidden Threat to Food Security. Report by ICP Vegetation (International Cooperative Programme on Effects of Air Pollution on Natural Vegetation and Crops). Centre for Ecology and Hydrology, Bangor/UK, p. 116.

Monks, P.S., Granier, C., Fuzzi, S., Stohl, A., et al., 2009. Atmospheric composition change - global and regional air quality. Atmos. Environ. 43, 5268-5350.

MTC, 2009. Ministério de Ciência e Tecnologia, 2009. Inventário brasileiro das emissões e remoções antrópicas de gases de efeito estufa: informações gerais e valores preliminares. http://www.mct.gov.br/index.php/content/view/ 310922/Segundo_Inventario_Brasileiro_de_Emissoes_e_Remocoes_Antropicas_ de_Gases_de_Efeito_Estufa.html.

Nakazato, R.K. Rinaldi, M.C.S., Domingos, M., 2014. Will technological modernization for power generation at an oil refinery diminish the risks from air pollution to the Atlantic Rainforest in Cubatão, SE Brazil? Environ. Pollut. 196, 489-496.

Pan, Y., Birdsey, R.A., Fang, J., Houghton, R., Kauppi, P., Kurz, W.A., Phillips O.L,Shvidenko, A., Lewis, S.L., Canadell, J.G., Ciais, P., Jackson, R.B., Pacala, S.W., McGuire, A.D., Piao, S., Rautiainen, A., Sitch, S., Hayes, D., 2011. A large and persistent carbon sink in the world's forests. Science 333, 988-993. 
Paoletti, E., de Vries, W., Mikkelsen, T., Ibrom, A., Larsen, K.S., Tuovinen, J.-P., Serengil, Y., Yurtseven, I., Wieser, G., Matyssek, R., 2013. Key indicators of air pollution and climate change impacts at forest supersites. In: Matyssek, R., Clarke, N., Cudlin, P., Mikkelsen, T., Tuovinen, J.-P., Weiser, G., Paoletti, E. (Eds.), Climate Change, Air Pollution and Global Challenges: Understanding and Solutions from Forest Research, Dev. Environ. Sci., vol. 13. Elsevier; Netherlands, pp. 497-518.

Rezende, F.M., De Souza, A.P., Buckeridge, M.S., Furlan, C.M., 2014. Is guava phenolic metabolism influenced by elevated atmospheric $\mathrm{CO}_{2}$ ? Environ. Pollut. 196, 483-488.

Ritter, W., Lehmeir, C.A., Winkler, J.B., Matyssek, R., Grams, T.E.E., 2014. Contrasting carbon allocation responses of juvenile European beech (Fagus sylvatica) and Norway spruce (Picea abies) to competition and ozone. Environ. Pollut. 196, 534-543.

Sitch, S., Cox, P.M., Collins, W.J., Huntingford, C., 2007. Indirect radiative forcing of climate change through ozone effects on the land-carbon sink. Nature 448, 791-795.

Veado, M.A.R.V., Arantes, I.A., Oliveira, A.H., Almeida, M.R.M.G., Miguel, R.A., Severo, M.I., Cabaleiro, H.L., 2006. Metal pollution in the environment of Minas Gerais State - Brazil. Environ. Monit. Assess. 117, 157-172.

Weigt, R., Haeberle, K.-H., Roetzer, T., Matyssek, R., 2014. Whole-tree seasonal nitrogen uptake and partitioning in adult Fagus sylvatica L. and Picea abies L. [Karst.] trees exposed to elevated ground-level ozone. Environ. Pollut. 196, 511-517.
Rainer Matyssek

Technische Universität München, Ecophysiology of Plants, FreisingWeihenstephan, Germany

Alessandra R. Kozovits

Universidade Federal de Ouro Preto, Instituto de Ciencias Exatas e Biologicas, Ouro Preto, Brazil

Gerhard Wieser

Federal Office \& Research Centre for Forests, Alpine Timberline Ecophysiology, Innsbruck, Austria

${ }^{*}$ Corresponding author E-mail address: matyssek@wzw.tum.de (R. Matyssek).

Available online 19 September 2014 